\title{
Assessment of the Potential for Biodegradation of Petroleum Hydrocarbons in the Railroad Industrial Area, Fairbanks, Alaska, 1993-94
}

U.S. GEOLOGICAL SURVEY

Open-File Report 98-287

Prepared in cooperation with the

Alaska Department of Natural Resources

Division of Mining and Water Management 


\section{U.S. DEPARTMENT OF THE INTERIOR BRUCE BABBITT, Secretary}

U.S. GEOLOGICAL SURVEY

Thomas J. Casadevall, Acting Director

Use of trade names in this report is for identification purposes only and does not constitute endorsement by the U.S. Geological Survey.

For additional information:

District Chief

U.S. Geological Survey

4230 University Drive, Suite 201

Anchorage, AK 99508-4664
Copies of this report may be purchased from:

U.S. Geological Survey

Branch of Information Services

Box 25286

Denver, CO 80225-0286

http://www-water-ak.usgs.gov 


\section{CONTENTS}

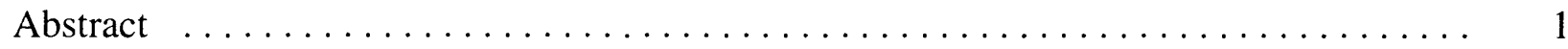

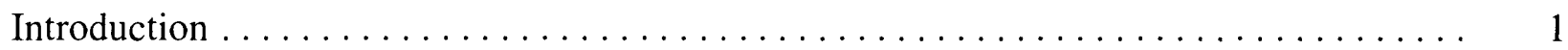

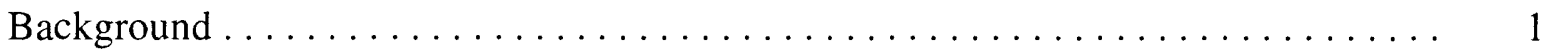

Location and Description of the Study Area...................... 2

Purpose and Scope................................... 4

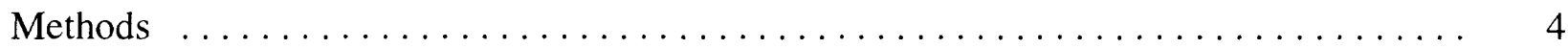

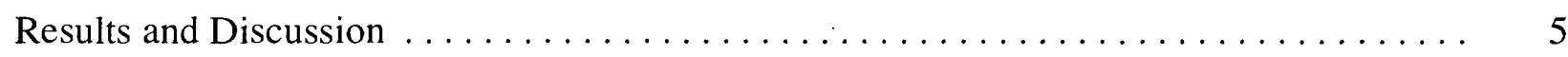

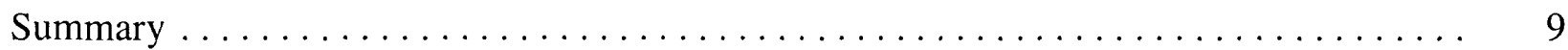

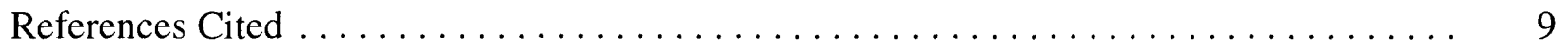

\section{FIGURES}

1. Map showing location of Fairbanks, Alaska, and the Fairbanks Railroad Industrial Area, with monitoring well locations. ..................

2. Graph showing the most probable number of gasoline-degrading microorganisms correlated with the BTEX concentration in ground-water samples collected in September 1994 from the Fairbanks Railroad

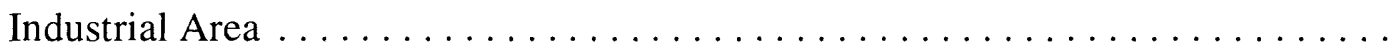

3. Graph showing the percent benzene mineralized over time in ground-water samples from contaminated and uncontaminated wells ...............

4. Graph showing the percent glutamate mineralized in ground water after incubation for two days at $22{ }^{\circ} \mathrm{C}$ and $15{ }^{\circ} \mathrm{C}$ for uncontaminated (AR27)

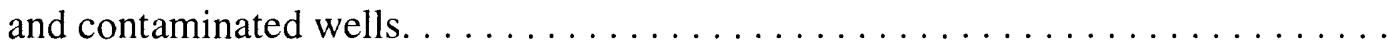

5. Graphs showing mineralization of glutamate, naphthalene, and benzene in ground-water samples with and without nutrient addition..............

\section{TABLES}

1. Benzene, toluene, ethylbenzene, and xylenes (BTEX) concentrations measured in ground-water samples from wells in the Railroad Industrial Area near Fairbanks, Alaska. . . . . . . . . . . . . . . . . . . . .

2. The most probable number of gasoline-degrading microorganisms and the total benzene, toluene, ethylbenzene, and xylenes (BTEX) concentration in ground-water samples from wells in the Fairbanks Railroad Industrial Area, in September $1994 \ldots \ldots \ldots \ldots \ldots \ldots \ldots \ldots \ldots$

3. Benzene mineralization potentials and the total benzene, toluene, ethylbenzene, and xylenes (BTEX) concentration measured in ground water collected in April 1994 from the Fairbanks Railroad Industrial Area . . . . . .

4. The effect of temperature on glutamate mineralization potentials for ground-water samples collected from the Fairbanks Railroad Industrial Area,

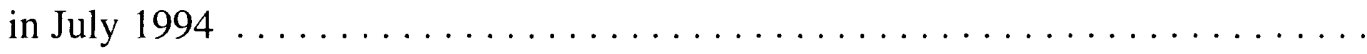


5. The effect of added nutrients on mineralization potentials for ground-water samples collected from the Fairbanks Railroad Industrial Area, in July 1994 . . . . .

6. Dissolved oxygen measured in ground-water samples from wells in the

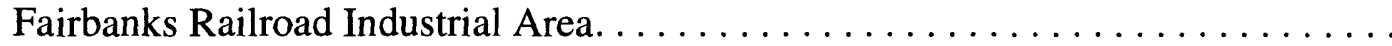

\section{ABBREVIATED WATER-QUALITY UNITS}

Chemical concentration and water temperature are given only in metric units. Chemical concentration in water is given in grams per liter $(\mathrm{g} / \mathrm{L})$, milligrams per liter $(\mathrm{mg} / \mathrm{L})$, or micrograms per liter $(\mu \mathrm{g} / \mathrm{L})$. Milligrams per liter is a unit expressing the solute mass per unit volume (liter) of water. One thousand micrograms per liter is equivalent to 1 milligram per liter. For concentrations less than 7,000 milligrams per liter, the numerical value is about the same as for concentrations in parts per million.

$\mathrm{mL}$, milliliters

$\mu \mathrm{L}$, microliters

dpm, disintegrations per minute

In this report, temperature is reported in degrees Celsius $\left({ }^{\circ} \mathrm{C}\right)$, which can be converted to degrees Fahrenheit $\left({ }^{\circ} \mathrm{F}\right)$ by the following equation:

$$
{ }^{\circ} \mathrm{F}=1.8\left({ }^{\circ} \mathrm{C}\right)+32
$$




\title{
Assessment of the Potential for Biodegradation of Petroleum Hydrocarbons in the Railroad Industrial Area, Fairbanks, Alaska, 1993-94
}

\author{
By Joan F. Braddock, Peter Catterall, and Sharon A. Richmond
}

\section{Abstract}

Many technologies for the clean-up of petroleum-hydrocarbon contaminated sites depend on microbial degradation of the pollutant. In these technologies the site may be modified to enhance microbial activity, or may simply be monitored for naturally occurring microbial activity. In either case, an important aspect of site assessment for these technologies is to determine if the microorganisms present at the site have the potential to break down contaminants under the prevailing environmental conditions. We examined the numbers and activity of hydrocarbon-degrading microorganisms in ground water collected from petroleum-hydrocarbon contaminated and uncontaminated wells at the Railroad Industrial Area near Fairbanks, Alaska. We found that the population of gasoline-degrading microorganisms in ground water was correlated to the degree of contamination by benzene, toluene, ethylbenzene and xylenes (BTEX). We also found that these organisms could actively mineralize these types of compounds in laboratory mineralization assays. Increasing temperature and adding nutrients both enhanced the rate of mineralization in the laboratory, but measurable degradation still occurred under conditions similar to those found in the field. Dissolved oxygen in ground water at this site ranged from 0 to 3.6 milligrams per liter. Therefore, oxygen may not always be available to microorganisms as a terminal electron acceptor. Preliminary geochemical evidence from the field indicates that alternative electron acceptors such as Fe(III), sulfate, or nitrate may be used, contributing to degradation of contaminants at this site.

\section{INTRODUCTION}

\section{Background}

Many organic contaminants, including petroleum hydrocarbons, can be degraded by microorganisms. Biodegradation can include everything from minor changes to a complete breakdown of the starting compound. When a complete breakdown to inorganic components (such as carbon dioxide and water) of the original compound occurs, the process is called mineralization. At some contaminated sites, conditions are favorable for microbial breakdown of contaminants. If the biodegradation at such a site is proceeding at an acceptable level, human intervention may not be necessary. This situation is called "natural attenuation" or "intrinsic bioremediation." Generally, intrinsic bioremediation is monitored with time and the only action a site may require is a sampling schedule. At other sites, some intervention may be necessary to enhance the biodegradation to an acceptable level. This is generally termed "enhanced bioremediation." Many systems have been designed to improve the level of microbial activity in breaking down contaminants. 
To understand what factors might be important in optimizing the conditions for bioremediation, it is necessary to understand something about the reasons why microorganisms break down organic contaminants. The types of microorganisms that biodegrade organic contaminants do so because they can use these compounds to produce energy for growth and carbon to build new cells. New cells are primarily made up of carbon, nitrogen, phosphorus, and several other mineral nutrients in lower concentrations. To complement the large amounts of carbon available from organic contaminants, a source of nitrogen or phosphorus may be important at many sites to allow microbial growth and, in turn, increase the rate at which the organic contaminant is broken down. Contaminant-degrading microorganisms also generally need oxygen or an alternate electron acceptor as a reactant in the process of producing energy from organic contaminants. At some environmental sites, such as in ground water, oxygen is commonly found only at low levels. Many bioremediation-enhancement strategies are based on increasing the concentration of oxygen to increase biodegradation. It is now known that many petroleum hydrocarbons, including some of the aromatic constituents found in gasoline (such as benzene and toluene), can be broken down by microorganisms under anaerobic conditions. In the anaerobic process, $\mathrm{Fe}$ (III) and compounds such as nitrate and sulfate may substitute for oxygen. These anaerobic processes are commonly very important in ground-water systems. In addition to the chemical requirements of microorganisms, it may be necessary to consider other factors at a particular site. These factors include the specific nature of the chemical pollutant and its concentration, and physical and chemical factors such as temperature and $\mathrm{pH}$.

One major problem in using bioremediation as a clean-up strategy for a contaminated site is that it can be difficult to establish that microorganisms are biodegrading the contaminant and to what degree degradation is occurring. Currently, no one measure can be used to fully assess bioremediation. To address this problem, in 1993, the National Research Council (NRC) convened a Committee on In Situ Bioremediation (NRC, 1993). This committee produced a set of guidelines to assess bioremediation success. Their recommendations are as follows:

"No one piece of evidence can unambiguously prove that microorganisms have cleaned up a site. Therefore, the Committee on In Situ Bioremediation recommends an evaluation strategy that builds a consistent, logical case for bioremediation based on converging lines of independent evidence. The strategy should include three types of information: (1) documented loss of contaminants from the site, (2) laboratory assays showing that microorganisms from site samples have the potential to transform the contaminants under the expected site conditions, and (3) one or more pieces of information showing that the biodegradation potential is actually realized in the field."

The study described in this report was designed to document that microorganisms from the site have the potential to transform contaminants under site conditions. Changes in contaminant concentrations with time were monitored at the site in a complementary study (Lilly and others, 1996, see table 1).

\section{Location and Description of the Study Area}

The study area is located in the Railroad Industrial Area in Fairbanks, Alaska (fig. 1). Development in the vicinity began in the early 1900's, and the area, which still serves as the main railhead for Fairbanks, has been the location of commercial and industrial activities since that time. Previous studies have indicated the presence of petroleum hydrocarbons and chlorinated solvents in ground water in the area. Ground-water wells have been monitored since 1993 (Kriegler and Lilly, 1995), and the extent of the migration of these compounds is presented by Lilly and others (1996). 


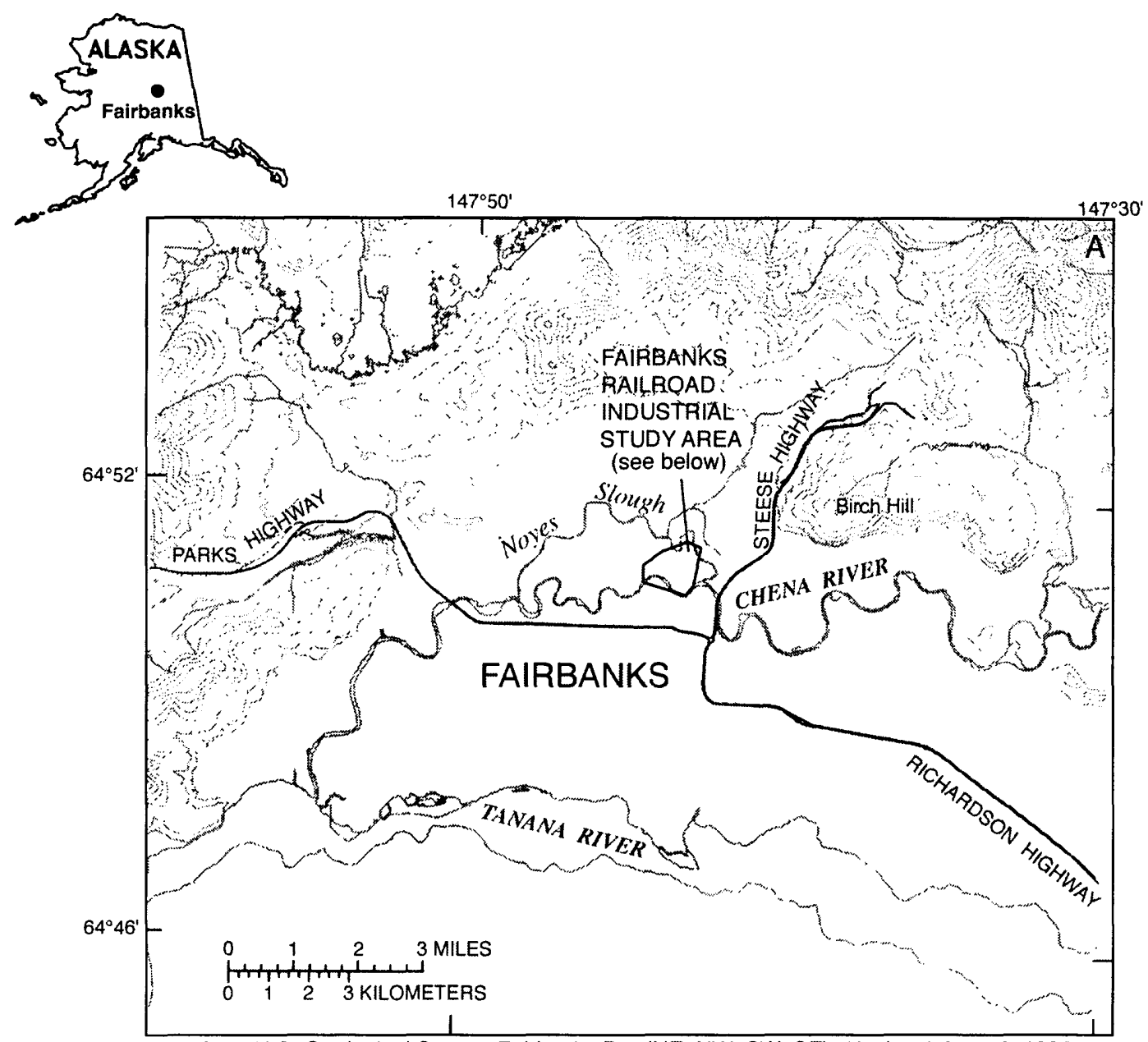

Base from U.S. Geological Survey, Fairbanks D-2 (NE, NW, SW, SE), Alaska, 1:25,000, 1992.

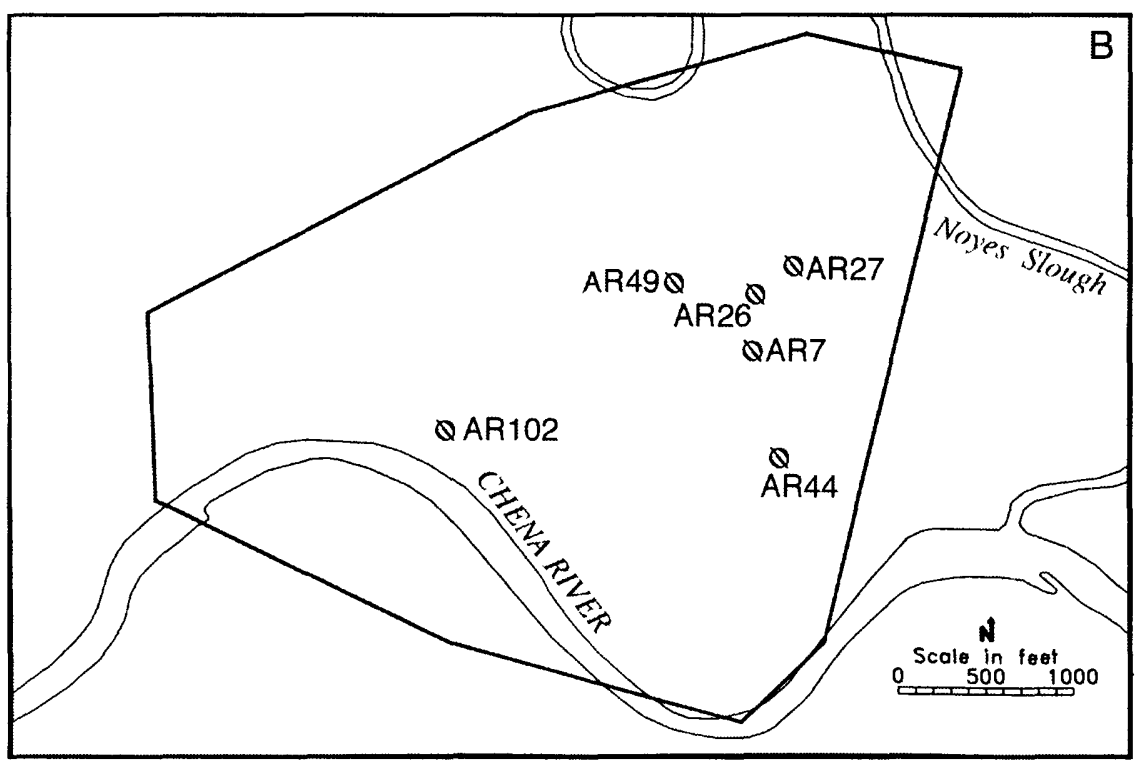

Figure 1. Location of Fairbanks, Alaska, and the Fairbanks Railroad Industrial Area (A), with monitoring well locations (B). 


\section{Purpose and Scope}

The two major objectives in studying the Railroad Industrial Area were (1) to determine the relative degree to which contaminants are moving from a specified boundary area with time (Kriegler and Lilly, 1995; Lilly and others, 1996); and (2) to determine what kind of microorganisms are present in contaminated and uncontaminated ground water at the site, determine if those microorganisms can degrade petroleum hydrocarbons, and examine some of the factors that might influence the rate at which these microorganisms are able to break down petroleum hydrocarbons. The latter objective is the subject of this report.

\section{METHODS}

Samples were collected from monitoring wells purged with a peristaltic pump using 3/8-inch Teflon tubing (Lilly and others, 1996). During purging, the temperature, $\mathrm{pH}$, specific conductance, and dissolved oxygen were continuously monitored. When these properties had stabilized and at least three well casing volumes had been purged, samples were collected in sterile containers from a bailer for microbiological analyses. While microbial populations and activities associated with soil particles at the site may be different from those measured in well water, only well water was measured in this study due to difficulties in obtaining soil samples at the site.

Most probable number (MPN) assays were used to estimate microbial populations of gasoline degraders and heterotrophs. A sixtube miniaturized MPN procedure was modified from Brown and Braddock (1990), using 96-cell well plates. Tenfold serial dilutions of a ground-water sample were made in an isotonic (Ringer) solution (Collins and others, 1989). A multi-channel pipette was used to transfer $100 \mu \mathrm{L}$ of each dilution to replicate wells containing $100 \mu \mathrm{L}$ of either $4 / 5$ strength mineral salts medium (Bushnell-Haas (BH); Atlas, 1993) amended with $0.025 \mathrm{~g} / \mathrm{L}$ tetrazolium violet for gasoline degraders, or a heterotrophic culturing medium (R2A; Atlas, 1993) for heterotrophs. Each well of the gasoline-degrader plates was then spiked with one drop of filtersterilized gasoline. The plates were incubated for 14 days at room temperature before being scored for color development (gasoline degraders) or turbidity (heterotrophs), indicating positive growth.

Radiorespirometry was used to assay the benzene-, naphthalene- and glutamate-mineralization potentials of microorganisms in groundwater samples (modified from Brown and others, 1991). Radiolabeled benzene and naphthalene ([U- $\left.{ }^{14} \mathrm{C}\right]$-benzene and $\left[1-{ }^{14} \mathrm{C}\right]-$ naphthalene) were used as representative aromatic hydrocarbons. In a similar manner, heterotrophic mineralization potentials were measured using [U- $\left.{ }^{14} \mathrm{C}\right]$-L-glutamic acid. To determine whether nutrient availability limits carbon-substrate mineralization, samples were diluted in both a nutrient-containing mineral salts medium (BH; Atlas, 1993) and in a saline solution containing no added nutrients (Ringer; Collins and others, 1989). Ground water was diluted 50 percent by adding $5 \mathrm{~mL}$ ground water to $5 \mathrm{~mL}$ of either BH or Ringer in $40-\mathrm{mL}$ septa vials. Replicate vials of the diluted ground water were injected with $50 \mu \mathrm{L}$ of a $2-\mathrm{g} / \mathrm{L}$ solution (in acetone for benzene and naphthalene or water for glutamate) of radiolabeled substrate (about 50,000 dpm/50 $\mu \mathrm{L}$ ). The resulting initial concentration of added substrate was then $100 \mu \mathrm{g}$ per vial $(10 \mu \mathrm{g} / \mathrm{mL}$ slurry). At the end of the designated incubation period, microbial activity was stopped by adding $1 \mathrm{~mL} 10 \mathrm{~N} \mathrm{NaOH}$ to each vial. The samples were later re-acidified with $1.5 \mathrm{~mL} \mathrm{HCl}$ after which the radiolabeled $\mathrm{CO}_{2}$ was stripped into a $\mathrm{CO}_{2}$-sorbing scintillation cocktail and counted in a liquid-scintillation counter. All microbial assays were conducted under aerobic conditions. 


\section{RESULTS AND DISCUSSION}

We sampled several ground-water wells in the Railroad Industrial Area four times during 1993-94 (table 1). We found populations of microorganisms (heterotrophs) that can break down organic molecules (not necessarily petroleum hydrocarbons) in all the water samples measured (results not shown). More importantly, we found specific populations of microorganisms that degrade the types of contaminants, such as gasoline, found in some areas of the site. Furthermore, the populations of microorganisms that can specifically biodegrade gasoline present in ground water at the site were found in numbers proportional to the amount of BTEX (benzene, toluene, ethylbenzene and xylenes) in the same water samples (fig. 2, table 2). In other words, water samples from sites that had high concentrations of BTEX also had high numbers of gasoline degraders. In contrast, uncontaminated water samples contained few, if any, gasoline-degrading microorganisms. This correlation provided evidence that natural attenuation might be occurring in the Railroad Industrial Area.

Table 1. Benzene, toluene, ethylbenzene, and xylenes (BTEX) concentrations measured in ground-water samples from wells in the Railroad Industrial Area near Fairbanks, Alaska $[\mu \mathrm{g} / \mathrm{L}$, micrograms per liter]

\begin{tabular}{lrrrr}
\hline & \multicolumn{4}{c}{ BTEX concentration $(\mu \mathrm{g} / \mathrm{L})$} \\
\cline { 2 - 5 } Well & \multicolumn{4}{c}{ Date sampled } \\
\cline { 2 - 5 } & \multicolumn{1}{c}{$8 / 93$} & \multicolumn{1}{c}{$4 / 94$} & $7 / 94$ & \multicolumn{1}{c}{$9 / 94$} \\
\hline AR7 & 5,910 & 11,280 & 13,100 & $(1)$ \\
AR26 & 38 & 80 & 29 & 63 \\
AR27 & $<0.2$ & $<0.2$ & $<0.2$ & $<0.2$ \\
AR44 & 6,180 & 11,750 & 7,870 & 7,090 \\
AR49 & 1 & 47 & 5 & 45 \\
AR102 & $<0.2$ & $<0.2$ & $<0.2$ & $<0.2$ \\
\hline
\end{tabular}

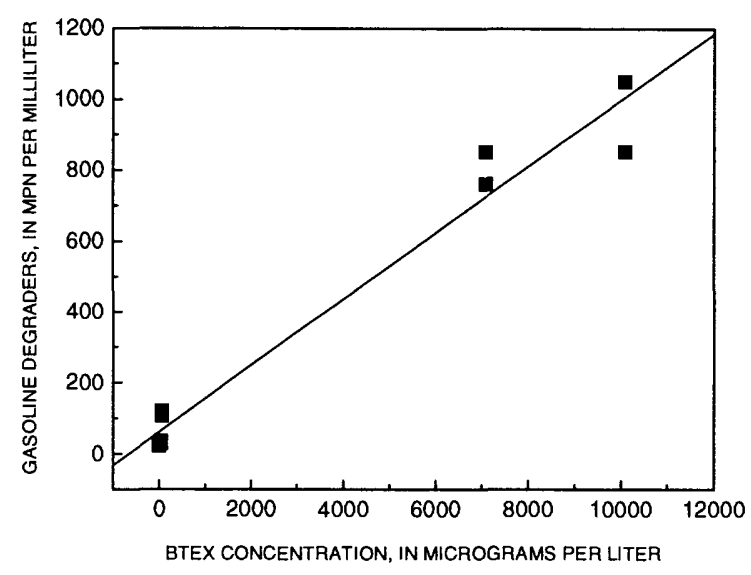

Figure 2. Most probable number (MPN) of gasoline-degrading microorganisms correlated $\left(r^{2}=0.96\right)$ with the BTEX concentration in groundwater samples collected in September 1994 from the Fairbanks Railroad Industrial Area.

Table 2. The most probable number of gasolinedegrading microorganisms and the total benzene, toluene, ethylbenzene, and xylenes (BTEX) concentration in ground-water samples from wells in the Fairbanks Railroad Industrial Area, in September 1994

[mL, milliliter; $\mu \mathrm{g} / \mathrm{L}$, micrograms per liter]

\begin{tabular}{lccc}
\hline Well & Replicate & $\begin{array}{c}\text { Gasoline } \\
\text { degraders } \\
(\text { cells/mL) }\end{array}$ & $\begin{array}{c}\text { BTEX } \\
\text { concentration } \\
(\mu \mathrm{g} / \mathrm{L})\end{array}$ \\
\hline AR7 & A & 1,050 & ${ }^{1} 10,097$ \\
& B & 852 & \\
AR26 & A & 107 & 63 \\
& B & 120 & \\
AR27 & A & 29 & $<0.2$ \\
& B & 22 & \\
AR44 & A & 852 & 7,090 \\
& B & 760 & \\
AR49 & A & 29 & 45 \\
& B & 36 & \\
\hline
\end{tabular}

'The BTEX concentration was not measured for well AR7 in September 1994; the BTEX value shown here and in figure 2 is the mean from the previous three samplings

${ }^{1}$ Well AR7 was not sampled for BTEX in September 1994 
Once we determined that microorganisms that biodegrade gasoline were present in contaminated ground water from the Railroad Industrial Area, we sought to establish whether or not these microorganisms have the potential to completely break down (mineralize to carbon dioxide and water) some of the chemical constituents found in gasoline. We used ground-water samples from three wells to examine the activity of the microbial population in laboratory assays. Ground water from two of these wells (AR44 and AR7) contained high levels of BTEX (about 10,000 $\mu \mathrm{g} / \mathrm{L}$; table 1) and high numbers of gasoline-degrading microorganisms (about 1,000 microorganisms $/ \mathrm{mL}$; table 2). Ground water from one well (AR27) contained no measurable BTEX and very low ( $<30$ microorganisms/mL; table 2 ) populations of gasoline-degrading microorganisms. After four days in a laboratory experiment conducted at room temperature $\left(22^{\circ} \mathrm{C}\right)$, the microbial populations in ground water from AR44 and AR7 were able to mineralize 15 to 30 percent of the added benzene to carbon dioxide (fig. 3, table 3). The microorganisms in AR27 were unable to mineralize any measurable quantity of the benzene in the same time period. These data show that acclimated microbial populations that can break down benzene, a toxic component of gasoline, are present in contaminated wells in the Railroad Industrial Area.

Several major factors have been found to control the rate and extent of natural attenuation in contaminated ground water. These factors include temperature, nutrient availability (especially nitrogen and phosphorus), and the concentration of dissolved oxygen (or other chemical species, such as nitrate, sulfate, and Fe(III)). The next step at the Railroad Industrial Area was to examine how these factors might affect the microbial activity at this particular site.

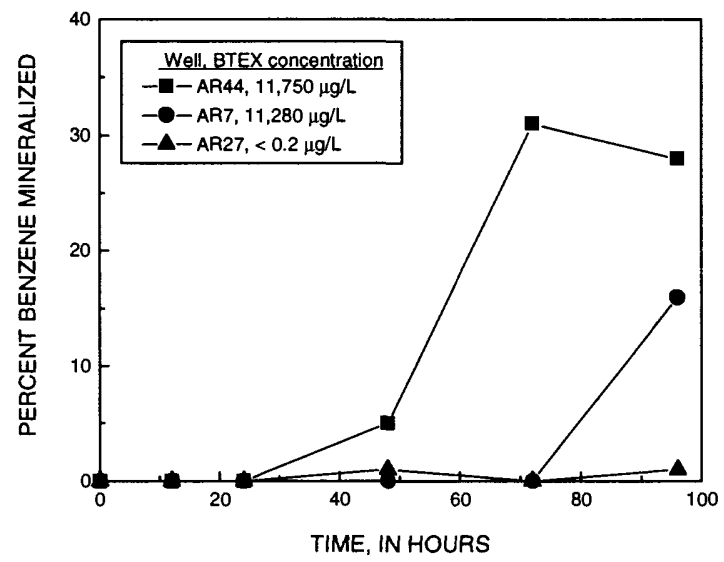

Figure 3. Percent benzene mineralized over time in ground-water samples from contaminated and uncontaminated wells.

Table 3. Benzene mineralization potentials and the total benzene, toluene, ethylbenzene, and xylenes (BTEX) concentration measured in ground water collected in April 1994 from the Fairbanks Railroad Industrial Area. Values for the benzene mineralization potentials are the means of duplicate analyses $[\mu \mathrm{g} / \mathrm{L}$, micrograms per liter]

\begin{tabular}{lccccccc}
\hline \multirow{2}{*}{ Well } & $\begin{array}{c}\text { BTEX } \\
\text { concentration } \\
(\mu \mathrm{g} / \mathrm{L})\end{array}$ & \multicolumn{6}{c}{ Benzene mineralization potential (percent mineralized) } \\
\cline { 3 - 8 } & & 0 & 0.5 & 1 & 2 & 3 & 4 \\
\hline AR7 & 11,750 & 0 & 0 & 0 & 0.2 & 0 & 16 \\
AR26 & 80 & 0 & 0.2 & 1.4 & 22 & 37 & 32 \\
AR27 & $<0.2$ & 0 & 0 & 0 & 1.1 & 0.6 & 1.1 \\
AR44 & 11,750 & 0 & 0 & 0.2 & 4.7 & 31 & 28 \\
AR49 & 47 & 0 & 0 & 0 & 0.2 & 0.6 & 5.2 \\
AR102 & $<0.2$ & 0 & 0 & 0 & 0.3 & 0.5 & 11 \\
\hline
\end{tabular}


We first examined the effect of temperature on the overall level of activity of microorganisms (total heterotrophs) in ground water from one uncontaminated and three contaminated wells. Samples were incubated in the laboratory at different temperatures. The overall activity of heterotrophic microorganisms was measured by examining the mineralization of glutamate, a good energy and carbon source for many microorganisms.

The natural temperature of the water in wells from the Railroad Industrial Area measured in April, June, July, and September averaged between 4 and $5{ }^{\circ} \mathrm{C}$. The water was slightly cooler in April and slightly warmer in September. When we examined the total activity of the heterotrophic microbial populationas indicated by glutamate mineralization-after two-day incubations in the laboratory at 4,10 , 15 and $22{ }^{\circ} \mathrm{C}$, we found no activity at 4 or $10^{\circ} \mathrm{C}$, and a large increase in activity between 15 and $22{ }^{\circ} \mathrm{C}$ (fig. 4, table 4). Samples run at $15{ }^{\circ} \mathrm{C}$ were incubated in a temperature-controlled chamber. Other samples were incubated at room temperature, which was approximately $22{ }^{\circ} \mathrm{C}$. When we incubated samples for longer periods of time ( 6 days for glutamate and 10 days for naphthalene and benzene), we found activity at $10{ }^{\circ} \mathrm{C}$. For example, when nutrient effects were measured at $10^{\circ} \mathrm{C}$ (fig. 5 , table 5), we found that microorganisms from contaminated wells AR44 and AR7 were able to completely break down 20 and 35 percent, respectively, of the naphthalene added. Benzene, another petroleum hydrocarbon, was also degraded after 10 days at $10^{\circ} \mathrm{C}$ by microorganisms from the same two contaminated wells. Bradley and Chapelle (1995) reported that microorganisms in sediment samples from Adak, Alaska, where in situ temperatures were about $5{ }^{\circ} \mathrm{C}$, could mineralize toluene when incubated at $5{ }^{\circ} \mathrm{C}$. Therefore, rates of hydrocarbon degradation may occur in cold ground- water systems at rates higher than previously thought.

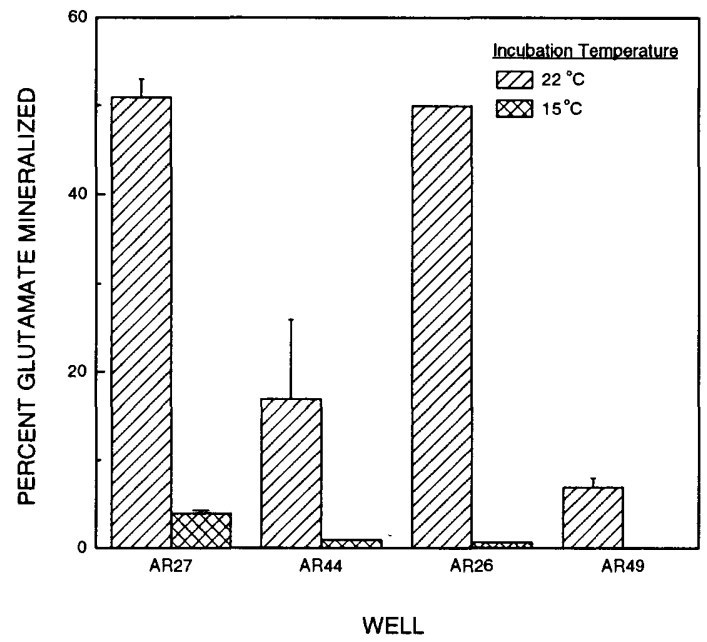

Figure 4. Percent glutamate mineralized in ground water after incubation for two days at $22^{\circ} \mathrm{C}$ and $15^{\circ} \mathrm{C}$ for uncontaminated (AR27) and contaminated wells. Mean BTEX concentrations for these wells can be found in table 1. Error bars represent standard error.

Table 4. The effect of temperature on glutamate mineralization potentials (a measure of heterotrophic microorganism activity) for groundwater samples collected from the Fairbanks Railroad Industrial Area, in July 1994. Values shown are the means of triplicates $\left[{ }^{\circ} \mathrm{C}\right.$, degrees Celsius $]$

\begin{tabular}{ccc}
\hline & \multicolumn{2}{c}{$\begin{array}{c}\text { Glutamate mineralization potential } \\
\text { (percent mineralized) }\end{array}$} \\
\cline { 2 - 3 } & $15^{\circ} \mathrm{C}$ & $22^{\circ} \mathrm{C}$ \\
\hline AR26 & 1 & 50 \\
AR27 & 4 & 51 \\
AR44 & 1 & 17 \\
AR49 & 0 & 7 \\
\hline
\end{tabular}



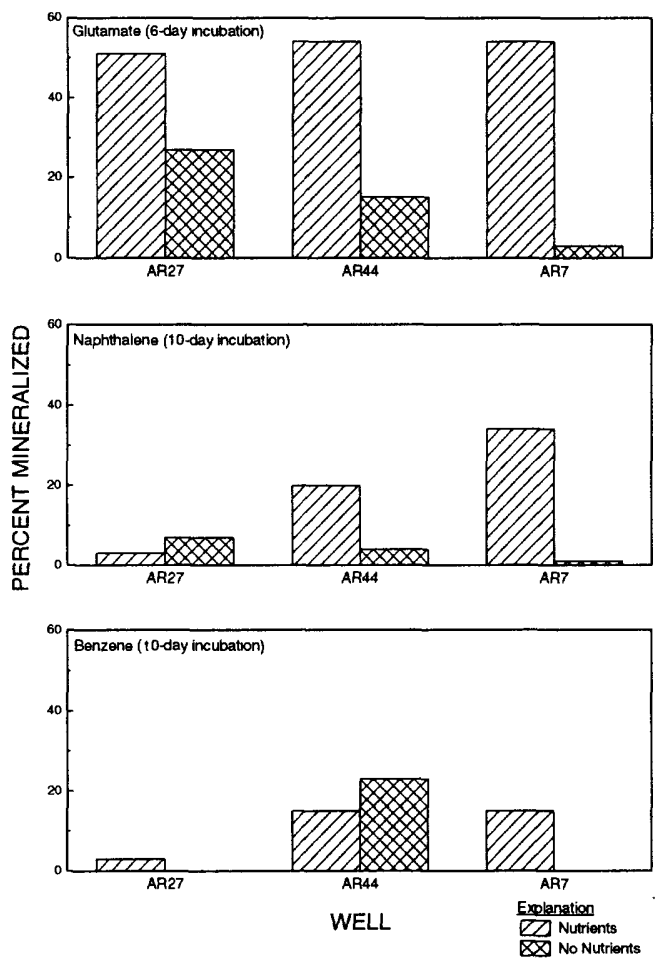

Figure 5. Mineralization of glutamate, naphthalene, and benzene in ground-water samples with and without nutrient addition. These laboratory assays were incubated at $10^{\circ} \mathrm{C}$.
Nutrient (nitrogen and phosphorus) additions stimulated microbial activity in most of the laboratory experiments (fig. 5, table 5). The results shown in figure 5 indicate that nutrient additions might stimulate microbial activity in the field. However, it is important to note that microbial degradation of all three substrates was occurring even in the absence of added nutrients. This implies that while biodegradation at the site might be increased by nutrient additions, naturally occurring nutrients are adequate for the microbial breakdown of petroleum hydrocarbons.

A third factor that can influence the rate of biodegradation is oxygen availability. We have not been able to clearly determine how great an effect oxygen concentrations have on biodegradation activity at the Railroad Industrial Area. Dissolved-oxygen concentrations in ground water from wells sampled in this study ranged from 0 to $3.6 \mathrm{mg} / \mathrm{L}$ (table 6). Ground water from other wells sampled in the same area, during the same time period of this study, had dissolved-oxygen concentrations as high as $7 \mathrm{mg} / \mathrm{L}$ (well oxygenated). It is thought that aerobic microbial activity is greatly inhibited at dissolved-oxygen concentrations of less than

Table 5. The effect of added nutrients on mineralization potentials for ground-water samples collected from the Fairbanks Railroad Industrial Area, in July 1994 . All samples were incubated at $10^{\circ} \mathrm{C}$; samples for glutamate mineralization potentials were incubated for 6 days, and for naphthalene and benzene, 10 days. Values shown are the means of triplicates

\begin{tabular}{|c|c|c|c|c|c|c|}
\hline \multirow{3}{*}{ Well } & \multicolumn{6}{|c|}{ Mineralization potential (percent mineralized) } \\
\hline & \multicolumn{2}{|c|}{ Glutamate } & \multicolumn{2}{|c|}{ Naphthalene } & \multicolumn{2}{|c|}{ Benzene } \\
\hline & Nutrients added & $\begin{array}{l}\text { No nutrients } \\
\text { added }\end{array}$ & Nutrients added & $\begin{array}{l}\text { No nutrients } \\
\text { added }\end{array}$ & Nutrients added & $\begin{array}{c}\text { No nutrients } \\
\text { added }\end{array}$ \\
\hline AR7 & 56 & 3 & 34 & 1 & 15 & 0 \\
\hline AR26 & 56 & 9 & 24 & 7 & (1) & (1) \\
\hline AR27 & 51 & 28 & 3 & 7 & 2 & 0 \\
\hline AR44 & 55 & 16 & 20 & 4 & 15 & 22 \\
\hline
\end{tabular}

\footnotetext{
${ }^{1}$ Values for benzene for well AR26 were not measured
} 
about 1-2 mg/L. However, under anaerobic conditions, other chemical species can be used by microorganisms as terminal electron acceptors. We have measured the levels of sulfate, nitrate, and $\mathrm{Fe}$ (III) (chemical species involved in the anaerobic breakdown of aromatic hydrocarbons; data not shown) in water from a few wells at the site. Preliminary evidence indicated that concentrations of sulfate were lower in ground water with measurable concentrations of BTEX than in water from uncontaminated wells. This result would be expected if sulfate is involved in an anaerobic microbial process. These types of geochemical measures may be used in the future to provide additional evidence that natural attenuation is being realized at this site.

Table 6. Dissolved oxygen measured in ground water from wells in the Fairbanks Railroad Industrial Area

[mg/L, milligrams per liter]

\begin{tabular}{lccc}
\hline \multirow{2}{*}{ Well } & \multicolumn{3}{c}{ Dissolved oxygen $(\mathrm{mg} / \mathrm{L})$} \\
\cline { 2 - 4 } & \multicolumn{3}{c}{ Date sampled } \\
\cline { 2 - 4 } & $4 / 94$ & $7 / 94$ & $9 / 94$ \\
\hline AR26 & 0.0 & 0.2 & 0.2 \\
AR27 & 2.2 & 3.6 & 2.5 \\
AR49 & 0.3 & 0.3 & 0.6 \\
AR102 & 0.3 & 1.4 & 0.2 \\
\hline
\end{tabular}

\section{SUMMARY}

This study focused on microbial indicators of natural attenuation at the Railroad Industrial Area near Fairbanks, Alaska. At this site we found that gasoline-degrader populations in ground water were correlated with the degree of BTEX contamination. Uncontaminated ground water contained few gasolinedegrading microorganisms while contaminated ground water had high numbers of gasolinedegrading microorganisms. These microorganisms also could mineralize benzene to carbon dioxide in laboratory mineralization studies. In water from contaminated wells, about 15-30 percent of added benzene was mineralized after four days of incubation. Benzene mineralization activity was negligible during the same time period in water from uncontaminated wells. This indicates that microbial populations in contaminated ground water at the site are acclimated to the presence of benzene and have the potential to mineralize this compound in the field. We also used laboratory assays to examine how changes in temperature and nutrient supply might influence microbial activity. Increasing the incubation temperature increased the rate of mineralization of added substrates. However, measurable degradation of benzene and naphthalene was still achieved at $10{ }^{\circ} \mathrm{C}$ after 10 -day incubations. Adding nutrients $(\mathrm{N}$ and $\mathrm{P})$ generally stimulated microbial activity. But for at least one sample (AR44) with high levels of contaminants, mineralization rates were high even without nutrient additions. Oxygen availability is likely limiting microbial activity at the Railroad Industrial Area site. Although we did not explore the effect of oxygen availability to microorganisms in great detail, we did conduct a preliminary survey of the presence of other potential electron acceptors in well water from the site. We found preliminary evidence that other chemical species, such as sulfate, may contribute to microbial degradation of petroleum contaminants at this site.

\section{REFERENCES CITED}

Atlas, R.M, 1993, Handbook of microbiological media: Boca Raton, Florida, CRC Press, 1,079 p.

Brown, E.J., and Braddock, J.F., 1990, Sheen Screen, a miniaturized most probable number method for enumeration of oil-degrading microorganisms: Applied and Environmental Microbiology, v. 56, p. 3,895-3,896.

Bradley, P.M., and Chapelle, F.H., 1995, Rapid toluene mineralization by aquifer microorganisms at Adak, Alaska: implications for intrinsic bioremediation in cold environments: Environmental Science and Technology, v. 29, p. $2,778-2,781$. 
Brown, E.J., Resnick, S.M., Rebstock, C., Luong, H.V., and Lindstrom, J., 1991, UAF radiorespirometric protocol for assessing hydrocarbon mineralization potential in environmental samples: Biodegradation, v. 2, p. 121-127.

Collins C.H., Lyne, P.M., and Grange, J.M., 1989, Microbiological methods (6th ed.): London, Butterworths, $409 \mathrm{p}$.

Kriegler, A.T., and Lilly, M.R., 1995, Water-elevation, stream-discharge, and ground-water quality data in the Alaska Railroad Industrial area, Fairbanks, Alaska, May 1993 to May 1995: U.S. Geological Survey Open-File Report 95-364, 247 p. + plate.
Lilly, M.R., McCarthy, K.A., Kriegler, A.T., Vohden, James, and Burno, G.E., 1996, Compilation and preliminary interpretations of hydrologic and water-quality data from the Railroad Industrial Area, Fairbanks, Alaska, 1993-94: U.S. Geological Survey Water-Resources Investigations Report 96-4049, 45 p. + appendixes and plate.

National Research Council, 1993, In situ bioremediation: When does it work?: Washington, D.C., National Academy Press, 207 p. 